Pace University

DigitalCommons@Pace

$11-2009$

\title{
Climate Change and Sustainable Development: The Quest for Green Communities, Part II
}

John R. Nolon

Elisabeth Haub School of Law at Pace University

Follow this and additional works at: https://digitalcommons.pace.edu/lawfaculty

Part of the Environmental Law Commons, and the Land Use Law Commons

\section{Recommended Citation}

John R. Nolon, Climate Change and Sustainable Development: The Quest for Green Communities, Part II, Plan. \& Envtl. L., Nov. 2009 at 3, http://digitalcommons.pace.edu/lawfaculty/645/.

This Article is brought to you for free and open access by the School of Law at DigitalCommons@Pace. It has been accepted for inclusion in Pace Law Faculty Publications by an authorized administrator of DigitalCommons@Pace. For more information, please contact dheller2@law.pace.edu. 


\title{
Climate Change and Sustainable Development: The Quest for Green Communities-Part II
}

\author{
John R. Nolon
}

This is the second part of Professor John $R$. Nolon's two-part series on climate change mitigation through sustainable development law. Part I ran in October 2009.

\section{INTRODUCTION TO CLIMATE CHANGE MANAGEMENT: WHO DECIDES?}

In Part I, I argued that local governments should be partners with federal and state governments in managing climate change. This may sound incongruous to the ears of those listening to the debates over cap-and-trade legislation. In that context, state and local programs that cap, auction, tax, regulate, track, or otherwise attempt to manage greenhouse gas emissions are criticized on a number of grounds. The same can be said when the debate turns to standards for alternative fuels and vehicles. There is force to the argument that a comprehensive, national program is needed to prevent inefficiencies, inequities, and irregularities in a program that affects industries that function at a national and global level. From this, a generalization is framed: The emission of greenhouse gas causes global, not local, impacts, hence these are matters for national, not local or state, regulation.

As the Senate considers the American Clean Energy and Security Act (ACESA) with its cap-and-trade program and its national energy conservation codes for buildings, the debate over who decides how we should manage climate change becomes more critical. ${ }^{1}$ This is all the more urgent as the United Nations (U.N.) Climate Change Conference in Copenhagen draws near and our climate change leadership is scrutinized. What is involved in climate change management? What is the proper role in these matters for the federal government and its agencies? Is there room for state and local action? Are there different realms of engagement that vary depending on the type of initiative being considered? How can the resources and authority of all levels of government be coordinated for maximum effect?

Those who see climate change management strictly as a federal matter argue that because climate change is a national problem, the full taxing power, expertise, and technical resources of the federal government must be the dominant, if not undiluted, force in combating the problem. State and local initiatives will burden interstate commerce, impose undue costs on other states, and wreak havoc with industries as they try to keep track of and comply with a host of disparate state and local standards. At best, it is conceded, local and state governments should be assigned minor roles in tracking and reporting emission reductions, inspecting matters at the local level, issuing permits that comply with federally established standards, and aligning their programs with those established by Con- gress. They should occupy a subordinate role as junior partners or perhaps even associates in a national system of climate change management.

In the absence of federal leadership over the past decade, many state and local governments grew impatient and acted aggressively to control climatethreatening emissions. Through its Global Warming Solutions Act, California established a statewide cap on greenhouse gas emissions. ${ }^{2}$ It requires reductions to 80 percent of 1990 levels by 2050 through a combination of market and regulatory approaches. The lack of federal standards for tracking and reporting on greenhouse gas emissions led to the creation of a multistate Climate Registry to establish a uniform reporting protocol. ${ }^{3}$ Within the past three years, states have launched the Western Climate Initiative, the Midwestern Regional Greenhouse Reduction Accord, and the Regional Greenhouse Gas Initiative in the Northeast and mid-Atlantic states. ${ }^{4}$ More than half the states have mandated renewable electricity standards or implemented net metering policies. ${ }^{5}$ More than a quarter of the states have set energy-efficiency standards for utilities. ${ }^{6}$

More than 500 local governments have joined ICLEI-Local Governments for Sustainability (ICLEI) and pledged to inventory local emissions, establish emission targets, develop a local climate 
Nearly half of emissions, then, can be influenced by land use and development patterns that are shaped, under our legal system, by an assortment of federal, state, and local land use laws. action plan, and implement measures to achieve the targets. ${ }^{7}$ Nearly 1,000 mayors have signed the U.S. Conference of Mayors Climate Protection Agreement; it commits them to work toward the goal of reducing greenhouse gas pollution levels to seven percent below 1990 levels by 2012. ${ }^{8}$ I document below numerous state and local laws that reduce emissions and energy use through transit-oriented development (TOD), energy-efficient buildings, preserving the carbon-sequestering natural environment, and other clever applications of state police power and local land use authority.

Some of these state and local programs may rub against federal programs and policies as they emerge from an awakened Congress; others can reinforce and strengthen federal initiatives. Local and state land use control laws must provide a firm foundation on which to build an integrated federal approach to the management of climate change, while respecting the traditional roles of federal, state, and local government in these matters.

The following material focuses on climate-change mitigation, adaptation to unmitigated climate change, and creating resilient communities built to withstand the consequences of global warming. All of these initiatives are being undertaken currently at the local level in response to the evidence on the ground that climate change is occurring.

Domestically, we emit 7.1 gigatons of $\mathrm{CO}_{2}$ annually. ${ }^{9}$ The natural landscape sequesters approximately 15 percent of this $\mathrm{CO}_{2}$, leaving a net 6.1 gigatons. ${ }^{10}$ Sequestration is a mitigation strategy since net emissions can be reduced by increasing the number of acres in the sequestering environment through local natural resource preservation programs.

Communities are adopting green zoning and code strategies, such as TOD ordinances and enhanced energy-conservation code adoption and enforcement, to mitigate climate change impacts or achieve other local sustainable development objectives. $\mathrm{CO}_{2}$ can be dramatically reduced through these strategies because 16 percent of current $\mathrm{CO}$, emissions come from the tailpipes of personal vehicles and 32 percent emanate from the operation of residential and commercial structures. ${ }^{11}$ Nearly half of emissions, then, can be influenced by land use and development patterns that are shaped, under our legal system, by an assortment of federal, state, and local land use laws.

Part I of this commentary made the point that combating climate change requires that the full legal power, technical capacity, financial resources, and historical strengths of all levels of government be integrated into a single system of management, mitigation, and sustainable development. It also noted that congressional action that respects and builds on this normative experience is both more likely to pass and to succeed on the ground. ACESA, and other legislative proposals aimed at energy conservation, climate-change management, and sustainable development should be informed by the significant role local governments have already assumed, and use state and federal resources to coordinate and strengthen these initiatives.

Leaving aside the complex issues of how standards for cap-and-trade and alternative fuels and vehicles should be set, I examine how the techniques localities have already adopted for promoting sustainable development can be used to manage climate change. Within this context, I define the proper role for localities as partners of state and federal governments in an integrated approach to climate change management. If the examples and illustrations that follow are read charitably, they describe the compatible integration of local, state, and federal influences. If this bespeaks an accidental and fragmentary policy of integrated federalism, impending climate conditions urge that it become explicit and comprehensive.

\section{MANAGING CLIMATE CHANGE:} TRADITIONAL GOVERNMENTAL ROLES

"Climate change management" includes strategies that both "mitigate" and "adapt to" climate change. A federal capand-trade program mitigates by limiting or reducing emissions. A local zoning ordinance that orients future development toward the use of public transit systems also mitigates by reducing the number of automobile trips taken, thereby lowering tailpipe emissions. "Adaptation strategies" are needed to the extent that we are unable to fully mitigate the consequences of climate change caused by greenhouse gas emissions. Amendments by Congress to the Coastal Zone Management Act (CZMA) or the Disaster Mitigation Act of 2000 (DMA) that discourage new development on the coasts, in floodplains, or disaster-prone areas "adapt" to the consequences of unmitigated climate change: sea-level rise, increased flooding, and storm surges. Local land use plans that delineate disasterprone areas and zoning laws that prevent or harden development in those areas are also adaptation strategies.

These definitions help to shape the debate over the role of each level of government in these matters. There are different historical realms for federal, state, and local action regarding the matters subsumed by sustainable development and climate-change management. The broad outlines of existing legal norms in the field of sustainable development can be illustrated through a variety of anecdotal references.

The federal environmental legal system was created in the late 1960 s, beginning with the National Environmental Policy $\mathrm{Act}^{12}$ and followed rapidly by the Clean Air Act, ${ }^{13}$ the Clean Water Act, ${ }^{14}$ and a dozen other federal laws designed to prevent and clean up pollution caused by the private sector and left unabated by the land use control system driven by local governments. The signature approach of these federal laws was to create standards for pollution that cannot be exceeded and to provide stiff criminal and civil penalties for violations. A capand-trade program enacted to prevent dangerous levels of atmospheric greenhouse gases (air pollution) fits comfortably within this tradition.

Federal agencies are charged with the responsibility of enforcing antipollution standards. The emphasis of federal environmental law is on the central role of the federal government as the standard-setter and steward of a healthy environment. This focus all but obscures the importance of the role of local governments in land use control and environmental protection. Federal 
Most environmental damage today is caused by "nonpointsource" pollution that results from land uses that are the legal responsibility of local governments.

agencies have successfully reduced pollution from "point sources," such as smokestacks and water pipes. But most environmental damage today is caused by "nonpoint-source" pollution that results from land uses that are the legal responsibility of local governments. This is surely true of greenhouse gas emissions, the majority of which emanate from the tailpipes of millions of vehicles and the operations of countless buildings scattered throughout some 40,000 local communities in the 50 states. Federal attempts to influence local land use control in the interest of abating nonpoint-source pollution have been thwarted by a variety of legal, political, and practical obstacles. ${ }^{15}$ Insulated as they have been from federal intervention, many local governments have adopted green zoning, green planning, and local climate management initiatives that work well within our legal tradition as well.

Local governments, however, need encouragement, guidance, additional resources, technical assistance, and coordination if they are to succeed in mitigating and adapting to climate change. Here, too, we have a tradition. Federal and state legislatures have adopted a number of initiatives that encourage and influence local governments to regulate private land use. Under the National Flood Insurance Program of $1968,{ }^{16}$ the federal government provides private property owners insurance against damage caused by flooding, but only if local governments adopt and enforce building construction regulations in federally designated flood plains. Congress established land use policies for land development in coastal areas under the CZMA of $1972 .{ }^{17}$ It provides planning grants to states, which in turn grant funds to localities to adopt coastal development plans and adopt regulations that comply with the federal and state coastal protection principles.

States, too, adopt laws that direct and influence local land use regulation. Virginia requires its local governments to adopt comprehensive land use plans; ${ }^{18}$ certain cities are required to amend their comprehensive plans to designate one or more urban development areas (UDAs); a UDA is defined as an area "that is appropriate for higher density development due to proximity to transportation facilities, the availability of a public or community water and sewer system, or proximity to ... other developed areas." ${ }^{19}$ UDAs mitigate climate change by reducing vehicle-miles traveled (VMT) and the energy consumed by the generally smaller residences and thermally efficient, mixed use buildings that they foster.

Under Minnesota law, local land use plans must contain a component that addresses local open space protection, a strategy that encourages sequestration of $\mathrm{CO}$ and reduces net domestic emissions. ${ }^{20}$ The Minnesota state government assists its localities in land use regulation by providing them with model ordinances regarding the creation of urban growth boundaries, agricultural protection zones, and subdivision ordinances that encourage sustainable development. ${ }^{21}$

Under California's Environmental Quality Act, local governments must prepare an environmental impact report on any project that may have a significant impact on the environment. ${ }^{22}$ This can and in some cases must involve imposing conditions on land use proposals to mitigate their adverse impact on climate change. In July 2009, the New York Department of Environmental Conservation amended its regulations to guide local land use agencies in the process of assessing and mitigating the greenhouse gas emissions from larger scale land development projects. ${ }^{23}$ This guidance document lists a number of mitigating measures for land use agencies to consider: green roofs, energy-efficient building envelopes, high-albedo roofing, maximum interior day lighting, reuse of building materials, on-site renewable energy, and combined heat and power technologies, among others. ${ }^{24}$

\section{A COMPREHENSIVE REVIEW OF LOCAL INITIATIVES TO MANAGE CLIMATE CHANGE ${ }^{25}$ \\ Overview}

Local legislatures may adopt land use plans, zoning ordinances, and maps that provide the blueprint for the future development of their communities and, when aggregated, their region. They adopt local subdivision and site plan

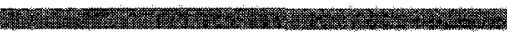 \\ LOCAL CLIMATE MANAGEMENT INITIATIVES}

1. Adopting standards that require buildings to accommodate plug-in vehicles and reduce idling

2. Facilitating use of renewable energy and on-site small power generation facilities through site plan requirements, financial incentives, zoning bonuses, and environmental impact mitigation requirements

3. Accommodating the growing, harvesting, and processing of biofuel feedstocks and eliminating zoning barriers to such practices

4. Promoting the local foods movement through zoning amendments that promote food production, from small gardening and livestock operations in existing neighborhoods to vertical farming in existing, underucilized buildings

5. Increasing cooling in urban neighborhoods through water-efficient landscaping and green or reflective roofs in all private and public development

6. Adopting methods of reducing energy use and emissions for local government buildings, equipment, operations, and vehicles

7. Zoning for neighborhood development that accommodates district energy systems in neighborhoods

8. Adopting zoning and building standards that require combined heat and power in buildings

9. Leveraging and enhancing the use of state and federal energy-saving and transportation enhancement programs including subsidies, grants, and loans

10. Building the professional infrastructure needed for green development services, verification methods, and weatherization programs through training, certification, and increased demand and support for these services

11. Encouraging low-impact retrofitting in existing private buildings, through efficiency standards, incentives, and education 
The economics of transit station development and rail and bus lines are dependent upon land use densities; there must be a sufficient number of commuters in a relevant group of adjacent communities to provide a minimal level of ridership throughout the area served by the transit system.

regulations and establish planning and zoning boards that review, approve, and impose conditions on applications for housing and commercial development. Municipalities can use these tools to play an active role in the management of climate change.

They have at their disposal the tools necessary to foster the shift from cardependent single-family neighborhoods to transit-oriented urban living. Such a shift reduces $\mathrm{CO}_{2}$ emissions by lowering VMT and increasing energy efficiency in buildings while reducing development pressures on carbon-sequestering open space. Municipalities can use their legal authority to protect local natural resources and open space to preserve and expand the carbon-sequestering environment. Through zoning, code, and site plan regulations they can require, or encourage, large and small wind and solar facilities.

The most promising among these initiatives in terms of reducing $\mathrm{CO}_{2}$ emissions and energy consumption are transit-oriented zoning and enhanced energy code and zoning standards, techniques illustrated here through a few case studies.

\section{Transit-Oriented Development}

Amending local zoning laws to house and employ more Americans in urban areas will cause a significant reduction in VMT while placing households in smaller, more energy-efficient homes, further reducing fossil fuel consumption and $\mathrm{CO}_{2}$ emissions. TOD planning and zoning locates housing and jobs near transit stops and significantly reduces the number and distance of vehicle trips.

To make transit systems feasible, land use planning among localities in a transportation region must be coordinated with regional and state transportation planning. In urban areas, regional metropolitan planning organizations (MPOs), organized under federal law, prepare capital plans for all types of transportation infrastructure, including transit services. Developing mechanisms to coordinate state and MPO transportation planning with local land use planning is key to successfully connecting higher density urban developments to transit services. Federal law requires MPOs to conduct planning processes that "provide for consideration of projects and strategies that will ... protect and enhance the environment, promote energy conservation, improve the quality of life, and promote consistency between transportation improvements and state and local planned growth and economic development patterns." 26

Local land use plans and zoning determine how much population will increase over time, and this, in turn, determines demand for various types of transportation services. Transit lines for rail and bus rapid transit services cannot be planned in isolation, station by station. The economics of transit station development and rail and bus lines are dependent upon land use densities; there must be a sufficient number of commuters in a relevant group of adjacent communities to provide a minimal level of ridership throughout the area served by the transit system. Rider habits must be diverse, as well, so that people are traveling to work, shop, entertainment, and home at various times during the day, increasing the cost efficiency of the service.

The Bloomington, Minnesota, city code provides for an "HX-R" zoning district (high intensity mixed use with residential) that is aimed at getting people out of their cars. ${ }^{27}$ It aims to reduce vehicle trips and VMT by maximizing high-density development in close proximity to transit. The ordinance prohibits drive-through uses that obstruct sidewalks and discourage walking. It provides a minimum density of 30 dwelling units per acre for residential development. It also provides a minimum Floor Area Ratio (FAR) of 1.5 and a maximum of 2.0. This maximum may be increased through density bonuses to encourage retail and service businesses, below-grade parking, development of plazas or parks, affordable housing, public art, and sustainable design.

Parking is restricted in the ordinance in order to promote walking, biking, and transit use. Parking must be located below grade, within structured ramps, or in individual on-street spaces parallel with and adjacent to lowvolume streets. Bicycle parking must be provided near building entrances. Development directly adjacent to transit stations must provide sidewalk and bikeway connections to the transit station as well as to adjacent sites. The Bloomington zoning strategy evinces a commitment to development that is truly transit oriented. It restricts parking, connects to nearby transit, and locates retail and service uses within short walks of residences, thereby reducing vehicle trips and VMT.

Yonkers, New York, adopted a highly detailed master plan for its central commuter station area that contained specifications for the types of development the city wanted on vacant land near the station. The zoning for the area was amended to provide as-of-right status for developments that conform to the design standards contained in the master plan. Compliance with New York's extensive state environmental review requirements was waived for such projects because the impacts of development contemplated by the master plan had already been studied in detail and mitigation of adverse environmental impacts was provided in the plan itself.

Early in this process, a developer was selected through a request-for-proposal process to plan the redevelopment of two centrally located sites immediately adjacent to the train station. As the city developed its plan and conducted its environmental impact review, the private developer began site planning and provided information to the city planners regarding economic and market realities. Information provided by citizens, environmental consultants, other professionals, and the developer were integrated as the process progressed and the master plan and designs for the two sites were adjusted.

The result is the development of Hudson Park, a two-phase project that contains 560 middle-income rental residential units, public pedestrian access to a renovated waterfront, restaurants, office and retail space, and immediate access to the train station through carefully designed walkways and entrances that provide security to riders. Hudson 
Some states have preempted local action of any kind regarding

energy conservation code adoption and enhancement.

Park is a dramatic TOD where the parking provided is approximately 50 percent less than the amount required by traditional urban zoning, made possible because the buil ings and area appeal to commuters who travel to work by train; the developer's marketing was designed to attract them.

The developer saved $\$ 25,000$ in development costs for each parking space not constructed, and residents save $\$ 6,000$ annually by owning one car instead of the usual two. Three high-quality restaurants and a number of retail stores catering to the middleincome populations of these buildings have appeared in the neighborhood. This project and the public amenities provided by the government to support it are credited with sparking considerable additional private sector interest in the marginally blighted area.

\section{Energy-Efficient Buildings}

There are a number of methods that can be used to reduce energy consumption in residential and commercial buildings. They include passive solar design, energy-saving lighting and appliances, multiple glazing, highly efficient ventilation and cooling systems, solar water heaters, insulation materials and technologies, high-reflectivity building materials, geothermal energy systems, combined heat and power systems for individual buildings, and district energy systems for multiple buildings.

In our legal system, the principal method of regulating building construction to achieve energy efficiency is the energy conservation code. Most states and cities that adopt such codes adopt the International Energy Conservation Code (IECC) promulgated by the International Codes Council (ICG). ${ }^{28}$ The ICC was established in 1994 as a nonprofit organization for the purpose of developing a single set of model construction codes, including building construction, plumbing, electrical, and energy conservation among other topics. The ICC was founded by Building Officials and Code Administrators International, Inc., the International Conference of Building Officials, and Southern Build- ing Code Congress International, Inc. These predecessor organizations developed three separate sets of model codes that were adopred or adapted by many of the 50 states within their regions.

When states adopt the ICC's energy conservation code, compliance with its standards is required before new or significantly renovated buildings are legally eligible to receive a certificate of occupancy $(\mathrm{CO})$ and begin operations. The $\mathrm{CO}$ is given by local code departments that are responsible for certifying that all construction meets the provisions of all applicable codes, including energy efficiency. This is another local land use responsibility that must be exercised effectively to ensure that new construction complies with the energy efficiency provisions of energy conservation codes.

The IECC is divided into two primary chapters. Discrete provisions regulate the construction of smaller residential buildings (one- and two-family homes and multifamily buildings three stories or less in height); other provisions regulate all other buildings, generally denominated "commercial" buildings. Most commercial buildings built in the last 30 years have been designed to conform to the IECC commercial building energy standards or Standard 90.1 , promulgated by the American Society of Heating, Refrigerating, and Air Conditioning Engineers (ASHRAE). Both the IECC and ASHRAE standards are developed through a process that invites the input of building industry representatives, code officials, architects, mechanical engineers, and lighting designers, among others.

Energy conservation codes regulate the building envelope, mechanical systems, and lighting. They provide minimum standards for these particular components of structures and, in most cases, stop short of mandating the use of high energy-efficiency technologies. They also do not regulate much of what consumes energy in completed buildings, such as consumer appliances and computers. Energy conservation codes, additionally, do not regulate building orientation and layout or the quality of construction, equipment maintenance, building operations, and occupant be- havior, which greatly affect the amount of energy consumed in a completed structure. As a result, for local energy conservation codes to achieve the maximum energy and climate efficiency, they must be "enhanced" to include means for reaching some of these aspects of building design, construction, and operations. Energy-efficiency code enhancements can take one of two forms: code provisions that strengthen the energy-efficiency provisions of building construction codes, or land use regulations and protocols that affect site planning, building design, and other environmental impacts of construction.

Some states have preempted local action of any kind regarding energy conservation code adoption and enhancement. They simply adopt an energy conservation code with standards that apply statewide and prevent local governments from adopting more restrictive provisions. Other states allow local governments to adopt provisions that achieve greater efficiency than the state code. ${ }^{29} \mathrm{~A}$ few states adopt no code at the state level but allow individual cities and towns to adopt energy codes if they wish. ${ }^{30}$ Massachusetts, which has a statewide energy code that preempts local action, adopted a package of enhanced code provisions that can be implemented locally-a so-called stretch code. ${ }^{31}$ This allows local governments to either apply the "base energy code," or, if they wish, to adopt and enforce the full set of enhanced provisions. The Massachusetts code enhancements for smaller residential buildings are based on the Energy Star for Homes standards ${ }^{32}$ and the Residential Energy Services Network rating approach. For commercial buildings, enhancements are based on the IECC 2009 energy conservation code, which is more restrictive than the Massachusetts base code, and the New Buildings Institute's Core Performance Guide for commercial buildings.

The state of New York allows local governments to adopt standards more restrictive than the New York State Energy Conservation Construction Code. The Town of Greenburgh amended its local code to add additional energy con- 
Viewed through the lens of climate-change mitigation, land use laws that double population densities in urban areas preserve a huge amount of the sequestrating environment. servation requirements. ${ }^{33}$ Greenburgh's local law requires that all new homes (small residential buildings) constructed in the town comply with New York State Energy Star-Labeled Homes requirement.'The New York State Energy Star Program provides several methods of making a home at least 15 percent more energy efficient than required by the state's base energy code, adapted from the IECC. These include more effective insulation, higher performance windows, more efficient heating and cooling equipment, a tighter building envelope to reduce air infiltration, and the use of various energy-efficiency products. As the U.S. Environmental Protection Agency (EPA) works to improve the Energy Star program it developed, it fills in some of the gaps in energy-efficiency compliance that exist in the IECC. These include, for example, field verification of the quality of construction and of mechanical systems; higher efficiency heating, cooling, and water heating equipment; and new requirements for energy-efficient lighting and appliances. ${ }^{34}$

\section{Sequestration}

Sequestration reduces domestic emissions by about 15 percent. Were it not for the absorption of $\mathrm{CO}_{2}$ by forests, grasslands, croplands, and urban trees, $\mathrm{CO}_{2}$ emissions in the United States would be 7.1 gigatons rather than a net $6.1 .^{35}$ If, through local land use zoning amendments, we were to double the density of dwelling units to accommodate the expected increase in the U.S. population of 100 million by 2039 , an area roughly the size of Connecticut would be saved from development. Viewed through the lens of climatechange mitigation, land use laws that double population densities in urban areas preserve a huge amount of the sequestrating environment.

Land use planning and regulation can further sequestration in a variety of ways as well, in addition to increasing density. Municipalities can adopt tree ordinances regulating the cutting, pruning, and replacement of trees on existing developed lots. They can adopt tree canopy objectives in their com- prehensive plan and aspire to increase the percentage of the community that is shaded. Trees provide windbreaks, reduce air conditioning costs, mitigate urban heat island effects, and make urban environments more comfortable and healthful. Municipalities can adopt timber-harvesting ordinances regulating the environmental impacts of forestry and promoting practices that increase carbon absorption by prescribing best stewardship practices.

Urban forests and vegetation can be expanded and enhanced by municipal tree planting programs as well as by zoning and site plan regulations that prevent tree removal, require tree replacement, and encourage or require developers to plant street trees, create small parks, build green roofs, provide landscape buffers, and create vegetated recreational and sitting areas or treelined walking and bike paths: All are part of desirable "green infrastructure." Density bonuses can be provided to developers of compact developments to compensate them for providing these sequestering amenities or cash contributions can be received in exchange for such bonuses, which can be used to purchase conservation easements on valuable open-space parcels that contain sequestering natural resources.

Through the use of cluster subdivision requirements and conservation subdivision standards, small landscape gains on individual development projects can add up to significant $\mathrm{CO}_{2}$ sequestration benefits while promoting the more localized gains of cooling the urban environment, reducing the heat island effect of densely developed neighborhoods, and securing public health benefits for the urban population. Clustering requires developers to preserve a percentage of the development parcel for open space and requires that it be left in its natural condition and be carefully managed to preserve community benefits of open land. Conservation subdivisions go further and require more aggressive conservation practices throughout the development.

The emerging field of "low-impact development" experiments with pervious alleys and green roofs in urban projects and, in compact suburban developments, vegetated swales that replace curbs and gutters for stormwater control, cluster development, tree retention, and retaining permeable topsoil on-site during and after construction. In rural communities, local zoning can protect and preserve fertile agricultural soils for farming.

The preservation of such resources provides valuable environmental benefits in addition to carbon sequestration: food production, wetlands and habitat preservation, stormwater management and flood prevention, watershed protection, and the prevention of erosion and sedimentation. Further carbon stabilization occurs when developing communities preserve existing farmland where food products can be produced closer to population centers, thereby reducing transportation costs. Seen though the lens of climate-change mitigation, wetlands preservation offers the additional benefit of carbon sequestration, because most wetlands have been undisturbed by previous development. ${ }^{36}$

\section{Adaptation}

The present concentration of $\mathrm{CO}_{2}$ in the atmosphere is roughly 385 parts per million (ppm). ${ }^{37}$ The 2007 report of the Intergovernmental Panel on Climate Change recommended that atmospheric $\mathrm{CO}_{2}$ concentration should not exceed 450 ppm. ${ }^{38}$ More recent studies state that the proper level of concentration is closer to $350 \mathrm{ppm}$, if not lower. ${ }^{39} \mathrm{Be}-$ cause $\mathrm{CO}_{2}$ lingers in the atmosphere for centuries, some scientists believe that the consequences of climate change caused by anthropogenic $\mathrm{CO}_{2}$ emissions are irreversible and require immediate attention to adaptive strategies. ${ }^{40}$

Among the most dramatic consequences of climate change is sea-level rise. A recent report from the U.S. Climate Change Science Program notes that "thoughtful precaution suggests that a global sea-level rise of 1 [meter] to the year 2100 should be considered for furure planning and policy discussions." ${ }^{41}$ Communities in coastal areas are becoming aware of the consequences that this threat poses to development in potentially inundated areas, and they 
Developing disaster-resilient communities and rebuilding after a disaster strikes requires both local competency and intergovernmental coordination. are starting to adjust their land use regulations accordingly. ${ }^{42}$

The Miami-Dade County Climate Change Task Force noted in its 2008 report that "[d]eveloped Miami-Dade County as we know it will significantly change with a $3-4$ foot sea level rise. Spring high tides would be at about +7 to $8 \mathrm{feer}$; freshwater resources would be gone; the Everglades would be inundated on the west side of Miami-Dade County; the barrier islands would be largely inundated; storm surges would be devastating; landfill sites would be exposed to erosion contaminating marine and coastal environments." 43

An earlier report from one of the task force committees emphasized the urgency "of reconsidering nearly every aspect of the county's management, zoning, infrastructure, and planning," and recommended establishing sealevel rise scenarios reflecting future rise to help determine what must be done to preserve habitability and what infrastructure will "need to yield to the rising sea." The report called for detailed documentation of infrastructure elevations, areas susceptible to erosion and pollution, drainage and storm-surge risks, and water supplies from across the county's various departments. The data and subsequent modeling of different sea-level rise scenarios have been compiled in the Committee's Climate Change Briefing $B o o k$, which discusses the county's vulnerability to sea-level rise and catalogs specific adaptive steps. ${ }^{44}$

The City of Bainbridge Island in Washington has explicitly addressed the potential for sea-level rise in the environment element of its comprehensive plan. Adopted in 2004, the plan recognizes that Bainbridge Island is potentially subject to sea-level rise related impacts including flooding and erosion. The overall goal of the element is to avoid adverse impacts where possible; to minimize, reduce, or eliminate impacts over time; and to compensate for unavoidable impacts. ${ }^{45}$ The plan outlines protections for critical areas including the transfer or purchase of development rights; protects marine fish and shoreline habitat; mandates no net loss of the city's remaining aquatic resources; requires the maintenance of vegetated buffers between proposed development and aquatic resources; and calls for the preservation of stream courses and the protection or restoration of natural functions of riparian habitat. ${ }^{46}$

The flooding component of the plan specifically recommends mitigating measures that include a limitation on development and the alteration of natural floodplains; preservation of stream channels and natural protective barriers; revision of the flood insurance rate map to reflect the natural migration of frequently flooded areas; and implementation of nonstructural protective methods such as setbacks and the use of natural

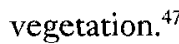

North Carolina's Coastal Areas Management Act of 1974 encourages cooperative land use planning between state and local governments. ${ }^{48}$ It is the state's policy that "adequate plans for post-disaster reconstruction should be prepared by and coordinated between all levels of government prior to the advent of a disaster." 49 The state design and construction guidelines for local hazard mitigation plans further provide that coastal communities should "outline a post-disaster permitting process that facilitates repairs but remains steadfast to the need to mitigate against future disasters." ${ }^{50}$ One way to accomplish this is to create a shortterm building moratorium to allow the community time to assess damage and consider mitigation measures after a disaster strikes.

Taking the initiative offered to it under North Carolina's Coastal Areas Management Act, the Town of Nags Head adopted a building moratorium that is triggered by disaster events. ${ }^{51}$ Nags Head is located on the outer banks, well known as a hurricane-prone area. Following a disaster, the law automatically imposes a 30-day building moratorium on the replacement of destroyed buildings. ${ }^{52}$ During that period, local planners and the legislative body may adjust zoning standards to correspond to any new inlets or eroded areas created by the storm and to adopt new disaster mitigation standards. ${ }^{53}$ Subsequent con- struction must then comply with these new area designations and regulatory standards. This innovative mechanism provides local officials the ability to redesign their standards to the circumstances existing after the disaster. ${ }^{54}$

\section{Resiliency}

Local governments can emulate Nags Head's initiative by using their delegated land use authority to create disaster-resilient communities so that they have increased capacity to adapt to the effects of natural disasters, resulting in less property damage, environmental impact, and loss of life. ${ }^{55}$ The Intergovernmental Panel on Climate Change concluded that the magnitude and frequency of extreme storm events are likely to change in response to climate change; these events include flash floods, wildfires, drought, hurricanes, and typhoons. ${ }^{56}$

The U.N. International Strategy for Disaster Reduction defines "resilience" as:

The capacity of a system, community, or society potentially exposed to hazards to adapt, by resisting or changing in order to reach and maintain an acceptable level of functioning and structure. This is determined by the degree to which the social system is capable of organizing itself to increase its capacity for learning from past disasters for better future protection and to improve risk reduction measures. ${ }^{57}$

Developing disaster-resilient communities and rebuilding after a disaster strikes requires both local competency and intergovernmental coordination. In 2000, Congress took stock of the nation's disaster response, recovery, and mitigation efforts and created a more coordinated approach to planning at all levels of government, one which assigns roles to each. Under legislation passed that year, the $\mathrm{DMA}^{58}$ provides a framework of federal, state, and local cooperation that is a model for a more comprehensive and integrated federal approach to climate-change management.

The DMA articulates national legislative objectives that provide an opportunity to enhance local mitigation 
New Hampshire municipalities are empowered to use a variety of innovative land use mechanisms to phase growth in an orderly way and to conserve open space and natural resources by clustering permitted development on discrete portions of land parcels. planning and implementation and to coordinate state and local land use planning and regulation to promote disaster mitigation. It provides that in order to qualify for federal hazard mitigation grants, state and local governments must develop and submit for federal approval a mitigation plan that outlines processes for identifying the natural hazards, risks, and vulnerabilities of the area under the jurisdiction of the government. ${ }^{59}$ It requires that state governments coordinate activities relating to hazard evaluation and mitigation by supporting development of local mitigation plans, providing technical assistance to local governments, and by identifying and prioritizing mitigation plans across the state. ${ }^{60}$

In New Hampshire, state law requires that if local governments adopt zoning regulations they must adopt master plans, which may contain various elements including a natural hazard component. ${ }^{61}$ Municipalities are authorized to develop coastal protection ordinances to carry out master-plan policies regarding the protection of natural resources and natural hazard areas. New Hampshire municipalities are empowered to use a variety of innovative land use mechanisms to phase growth in an orderly way and to conserve open space and natural resources by clustering permitted development on discrete portions of land parcels. ${ }^{62}$

New Hampshire adopted the Shorelands Protection Act to conform to the policies of the federal CZMA linking state and federal initiatives. ${ }^{63}$ The City of Dover responded by adopting an Overriding Districts Ordinance. ${ }^{64}$ Its authority to act is found in the state land use enabling act. ${ }^{65}$ The Dover ordinance links into the federal and state coastal initiative by protecting local wetlands, watercourses, and steep slopes in the state-designated shoreland areas within its jurisdiction. With the maintenance of high water quality as its objective, ${ }^{66}$ this local ordinance aims directly at the objectives of an international compact: The U.N. Convention on the Law of the Sea, which states that land-based activities should not contribute to the pollution of adjacent coastal waters. ${ }^{67}$

\section{TOWARD SUSTAINABILITY: GREEN} BUILDINGS AND NEIGHBORHOODS

Part I of this commentary provided three definitions applicable to individual buildings: green buildings, energy-efficient buildings, and highenergy technology buildings. Defining these terms is no mean feat. There are multiple and somewhat different definitions of green buildings emerging from sources such as the EPA, the National Association of Home Builders, the U.S. Green Building Council (USGBC), and various state agencies, including New York's Department of Environmental Conservation. The Federal Trade Commission (FTC) is watching as the green building market grows exponentially. It is considering amending its Guides for the Use of Environmental Marketing Claims to include guidance (more definitions) related to green buildings and construction. ${ }^{68}$ These guides serve the industry and are the basis for F'TC civil prosecutions for misleading green claims.

Traditional regulatory and public financial strategies provide the basis for the definitions used herein. Energyefficient buildings are those that comply with mandatory standards of state and local energy conservation codes, which can be enhanced to be more restrictive than model codes or minimum state standards. The costs they impose must be reasonable, meaning that the energy saved pays for the required energy conservation improvements within a relatively short time. High-energy technology buildings achieve even greater energy savings through technologies such as renewable wind and solar facilities or combined heat and power. Typically, the higher costs of these improvements militate against including them as code requirements. Owners can decide voluntarily to include these high-tech options because they are local protocols (recommendations) or because federal, state, or local tax, density, or dollar subsidies motivate them to do so.

Green buildings move beyond energy efficiency and accomplish one or more additional sustainable development objectives. Such buildings employ construction techniques, building designs, and operational systems that save water, reduce lighting needs, use recycled materials, or create a more healthful indoor environment. Green building standards of this type can be found in local zoning laws, subdivision and site plan standards, or review and approval protocols.

Part I also defined green neighborhoods. These are districts within communities where regulations, investments, and incentives are targeted to achieve a larger scale of operations for encouraging green buildings and providing neighborhood amenities and services that achieve the goals of sustainable development. Standards for green neighborhoods can be found in local zoning and land use regulations and practices, but may also require amendments to local and state capital budgets for the amenities and services needed, as well as the cooperation of regional transit agencies and private developers. More extensive planning and coordination among governmental agencies, capital budgets, land use regulation, and the private sector is needed to bring green neighborhoods to life.

\section{Green Buildings}

Some communities are moving beyond climate-change mitigation and energy conservation by requiring buildings to comply with the Leadership in Energy and Environmental Design (LEED) Green Building Rating System. This program was developed by the USGBC almost a decade ago to encourage developers to adopt sustainable green building and development practices through compliance with widely accepted performance criteria. LEED promotes a range of sustainability objectives by awarding points toward certification for performance in five key areas: Sustainable Sites, Water Efficiency, Energy and Atmosphere, Materials and Resources, and Indoor Environmental Quality.

The City of Boston incorporated LEED standards by including them in the Boston Zoning Code Green Building Amendments in 2007. These amendments "ensure that major building projects are planned, designed, constructed, and managed to minimize 
In some states, local governments can impose impact fees on new developments that are not "green" and award the proceeds to those that are. adverse environmental impacts; to conserve natural resources; to promote sustainable development; and to enhance the quality of life in Boston." ${ }^{69}$ The Boston legislation requires affected buildings to be LEED "certifiable," rather than "certified." Affected developers are required to design and construct a building to meet the minimum level of LEED certification requirements but are not required to apply for actual certification from the USGBC. ${ }^{70}$

Under Boston's LEED compliance approach, developers are allowed to choose which LEED standards to meet and to demonstrate to the city that the building is able to achieve certification, rather than to receive actual certification prior to the issuance of the CO. This approach may or may not achieve better energy conservation, but it does ensure that buildings achieve a variety of environmental benefits. The LEED for New Construction (LEED-NC) "energy and atmosphere" category includes measures that are not included in energy conservation codes, such as on-site renewable energy, enhanced building commissioning, enhanced refrigerant management, measurement and verification, and "green power." The "materials and resources" category includes building reuse and construction waste management, which indirectly save energy.

Another method available to communities is to use LEED standards as performance objectives or review protocols, rather than as requirements or conditions precedent to the issuance of the CO. This implicates the land use review and approval powers and processes of local governments and requires the planning commission and the development staff of the municipality to urge developers to comply with LEED to expedite the permitting process. Taking this approach allows the commission and staff to encourage compliance with the energy and atmosphere standards of LEED-NC in order to enhance its energy conservation code enforcement efforts should that be the policy emphasis of the city. Alternatively, LEED standards can be used as review protocols to achieve a variety of other sustainable development objectives.
Under special legislation adopted by the state legislature in 2008, the City of Syracuse, New York, is authorized to exempt LEED-certified buildings from local property taxes according to a schedule in the law that tracks the level of LEED certification and the type of building involved. ${ }^{71}$ New residential structures are eligible for property tax exemptions over a 15 -year period, starting with 100 percent exemptions for all levels of LEED certification; exemptions decline in later years to lesser degrees for the more stringent levels of certification.

Federal law provides energy tax credits to businesses that incorporate solat or geothermal energy technology, combined heat and power, small wind facilities, and fuel cells into building projects. ${ }^{72}$ New York offers a tax credit to owners of green buildings. ${ }^{73}$ That state's energy agency offers a wide variety of grants and loans to home owners, developers, and municipalities throughout the state. ${ }^{74}$ Developers, under New York land use law, can be offered density bonuses by local governments in exchange for providing building and neighborhood amenities such as energyconserving construction and vegetated roofs or street-level landscapes. ${ }^{75}$

In some states, local governments can impose impact fees on new developments that are not "green" and award the proceeds to those that are. Incentives like these can be combined with local legal requirements or used independently to achieve energy savings and environmental benefits that exceed otherwise applicable building and land use law.

\section{Green Neighborhoods}

Facilitating green infrastructure, adopting enhanced energy codes, or encouraging TOD development are individual municipal strategies to achieve green development. Local governments can approach sustainability more comprehensively through a neighborhood-wide and more holistic community approach.

Grand Rapids, Michigan, recently adopted Zone Grand Rapids (Zone GR), an ordinance that encourages mixed use development that preserves the character of Grand Rapids neighborhoods while promoting walkability, livability, and sustainability. ${ }^{76}$ Zone GR implements the vision of the Grand Rapids 2002 Master Plan, which is based on widely accepted sustainable development principles.

Developers of projects in Grand Rapids neighborhoods now find that their projects are compatible with the newest USGBC rating system, LEED for Neighborhood Development (LEED-ND). ${ }^{77}$ LEED-ND, like the Grand Rapids Master Plan and Zoning Code, is based on fundamental smart growth and sustainable development notions. It is a product of collaboration between the USGBC, the Natural Resources Defense Council, and the Congress for the New Urbanism. Like the other LEED certification categories, ND requires that projects meet certain prerequisites-preconditions to eligibility-and then earn a certain number of points to achieve various levels of certification.

LEED-ND certification is achieved by complying with requirements that are divided among five categories: Smart Location and Linkage (SLL), Neighborhood Pattern and Design (NPD), Green Infrastructure and Buildings (GIB), Innovation and Design Process, and Regional Priority Credits. ${ }^{78}$ Within the first three categories, SLL, NPD, and GIB, prerequisites are identified that embody the principles of sustainable development; they can also be used as a helpful guide for communities in amending their comprehensive plans, zoning and land use regulations, and in planning their public works budgets and projects. For many neighborhoods to support LEEDND certification, a partnership between municipal efforts of this type and private developers will be required.

SLL prerequisites, for example, are intended to "encourage development within and near existing communities and public transit infrastructure" and "preserve irreplaceable agricultural resources by protecting prime and unique farm and forest lands from development." 79 Zoning standards that foster development in existing neighborhoods or the use of distressed older buildings or brownfields will satisfy the LEED-ND requirement of smart location. Ordinances that permit transfer 
Zoning can allow district heating and cooling plants to be installed in certain buildings; land use review protocols can be used to encourage owners to provide them; and density bonuses can be granted to provide a financial incentive for such plants, or for solar panels or wind turbines.

of development rights from farm lands or other ecologically important areas to such areas further ND principles and manage climate change by preserving the sequestering environment and promoting more energy efficient human settlements.

NPD prerequisites aim to "promote livability, walkability, and transportation efficiency," as well as "promote communities that are physically wellconnected within and beyond development projects." 80 This can be achieved by increasing the density permitted by zoning to accommodate a transit agency's need for riders. LEED-ND, for example, requires that projects have a minimum FAR of 0.80 for commercial buildings or a minimum of seven dwelling units per acre for residential structures. ${ }^{81}$

A prerequisite in the GIB category offers guidance for municipalities regarding their energy conservation codes and practices. GIB Prerequisite 2 "[e] ncourage[s] the design and construction of energy-efficient buildings that reduce air, water, and land pollution and adverse environmental impacts from energy production and consumption." 82 To meet this precondition, a locality can enhance its energy conservation code to include greater efficiency standards for new and substantially renovated buildings and ensure that the code is properly enforced. Any newly constructed buildings that are four stories or higher must be 10 percent more energy efficient than required by ASHRAE 90.1-2007, which is the base energy conservation requirement for commercial buildings in many states. In addition, buildings undergoing major renovations must be five percent more efficient than this standard. ${ }^{83}$ Within a LEED-ND project, 90 percent of all new residential buildings that are three stories or lower and new multiunit residential buildings must meet Energy Star criteria or their equivalent. ${ }^{84}$

Beyond these prerequisites, the credits that may be earned under LEED-ND provide additional guidance to communities interested in amending plans, zoning, and capital budgets to achieve sustainable devel- opment and climate-change mitigation. Points are earned for projects located in neighborhoods with proper street networks, for example, and that provide for district heating and cooling facilitics in one or more buildings. Streets that are engineered for greater connectivity, with less drive-through activity on sidewalks, more pedestrian use and amenities, and paths for bikes and scooters, can be a capital budget priority and lower VMT while enabling project developers to earn points toward ND certification.

Zoning, site plan, and subdivision regulations also can be adjusted to provide for these types of street and travel features. Zoning can allow district heating and cooling plants to be installed in certain buildings; land use review protocols can be used to encourage owners to provide them; and density bonuses can be granted to provide a financial incentive for such plants, or for solar panels or wind turbines. GIB Credit 11 "encourages on-site renewable production to reduce the adverse environmental and economic impacts associated with fossil fuel energy production and use." ${ }^{85}$ Solar, wind, geothermal, small-scale/micro hydroelectric, and biomass facilities that reduce annual energy costs by five percent or more earn points in the GIB category. Greater energy cost savings earn additional points.

In May 2009, Charlotte County, Florida, passed a green building ordinance to incentivize sustainable development. ${ }^{86}$ The program offers developers fast-track permitting, marketing recognition by the county, monetary incentives in the form of rebates, credits, and reduced development plan review fees, increased zoning density, and reduced parking requirements. Projects that are LEED-ND certifiable are eligible for consideration under this ordinance. ${ }^{87}$

Las Vegas worked around its existing traditional zoning and design standards to make LEED-ND compliance possible for Union Park, a large mixed use development project on a 60 -acre site. It created and adopted a set of projectspecific design standards that specifically incorporate LEED-ND certification requirements for this individual project. ${ }^{88}$
Shortly after the inauguration of LEED-ND in 2007, the Illinois legislature passed the Green Neighborhood Grant Act for cities. This program awards grants covering 1.5 percent of total development costs in selccted green neighborhoods where developments are able to achicve LEED-ND certification. ${ }^{89}$ The program is administered by the Illinois Department of Commerce and Economic Opportunity.

These examples of green development at the neighborhood level illustrate the integration of sustainable development principles into local plans, budgets, and zoning laws, the encouragement of neighborhood-wide sustainable planning and development by state legislatures, and the development of independent standards by third-party experts at the national level that help localities integrate climate change mitigation, energy conservation, and other environmental benefits in a increasingly comprehensive strategy.

\section{CONCLUSION: AN INTTEGRATED LEGAL SYSTEM}

The task of creating an integrated system of law to promote sustainable development, manage climate change, and reduce energy consumption is not as complex or novel as it seems. There is evidence that Congress is capable of enacting framework laws, with reflexive provisions, that coordinate governmental roles and resources. Consider these examples:

- Federal transportation law provides funding for alternative modes of transportation, including transit, and establishes regional planning organizations that link with state and local transportation planning and capital spending, resulting in transit-oriented zoning such as that adopted by Bloomington, Minnesota.

- The federal CZMA establishes objectives for coastal development and preservation that encourages North Carolina to adopt its Coastal Areas Management Act to coordinate state and local planning. This led to the adoption of an aggressive coastal disaster management program at the local level in Nags Head. 
Proposals that respect and involve localities in their implementation are more likely to win widespread congressional approval and endure over time.
- The DHA makes state and local disaster management planning a prerequisite for receiving federal hazard mitigation funding and links to the CZMA, which also promotes hazard mitigation. Under a New Hampshire state law adopted in response, Dover implements a coastal overlay zone to make it more resilient in response to expected storm surges and tidal inundation. These federal, state, and local laws help implement the objectives of an international compact: the U.N. Convention on the Law of the Sea.

- Green buildings are facilitated by a combination of federal, state, and local tax incentive programs. Local code amendments requiring more energy efficiency in buildings incorporate Energy Star standards that are promulgated by the EPA and then adopted by state agencies to enhance local energy conservation code provisions. The incorporation of the IECC as a model for a national program in ACESA brings in the expertise of the building design and construction industry, whose representatives determine the provisions of that code.

Fragments of a proper national legal system are on the congressional legislative agenda. As the Senate considers the newly introduced American Glean Energy Leadership Act (ACELA) and the House-adopted ACESA, there is an unprecedented opportunity for Congress to get the legislative strategy right regarding not only energy consumption, but climate change and sustainable development.

The cap-and-trade provisions of ACESA have dominated the debate, focusing on businesses and industries that emit greenhouse gases. This obscures the importance of building construction, location, and land use. Buildings consume a significant amount of the electricity produced in the United States, much of it from coal-burning generation plants. They are responsible for nearly 40 percent of domestic $\mathrm{CO}_{2}$ emissions. Sixteen percent of $\mathrm{CO}_{2}$ comes from the tailpipes of personal vehicles that carry passengers, usually one at a time, from the buildings where they live to the buildings in which they work and to their other daily destinations. Where and how buildings are built can cause or prevent flooding, land erosion, water sedimentation, stormwater runoff, the urban heat island effect, and water and air pollution: issues of great concern to the American public that are part of the larger sustainable development agenda. Transportation, building construction, and land use patterns must be dealt with together as this new federal legislative agenda emerges.

This calls for a more comprehensive approach to lawmaking than evidenced in the laudable provisions of ACESA and ACELA. Congress should reshape the provisions of both bills and recast them as a framework law that integrates the accepted roles and responsibilities of the federal, state, and local governments for buildings, land use, and transportation. Taking such an approach is wise both politically and strategically. Local governments, with proper state and federal support, can employ a variety of strategies to mitigate climate change by reducing $\mathrm{CO}_{2}$ emissionsand to reduce dependence on foreign oil in the process-thereby enhancing national security and protecting the global environment by acting locally. Proposals that respect and involve localities in their implementation are more likely to win widespread congressional approval and endure over time.

Enforcement of an energy-efficiency code, the centerpiece of Title II of ACESA, is just one of many suitable approaches to achieve these objectives. Congress can encourage and enable state and local governments to use their legal power to adopt model energy base codes; to enhance those codes by adopting Green Globe, National Association of Home Builders, the New Building Institute, or EPA energy-efficiency standards; to incentivize the use of highenergy-efficiency technologies in buildings and neighborhoods; and to green those buildings and neighborhoods with pervious alleys, green roofs, street trees, water-efficiency technologies, and landscaping appointments using the expertise of local task forces or by incorporating the standards of the USGBC's LEED certification program.
Congress should quantify how much $\mathrm{CO}_{2}$ must be reduced and how much energy must be saved to meet national needs. It should allocate discrete responsibility for mitigation to cap-andtrade, more efficient fuels and vehicles, and to green development. These goals can be set by federal law; methodologies can be established and metrics developed to create standard baselines and monitoring systems for state and local initiatives.

Regarding green development, the federal government should then provide data, technology, best practices, and model laws to state and local governments and provide funding to encourage them to adapt successful climatechange management practices and laws to fit their unique circumstances. This approach builds on the traditional roles and responsibilities of state and local governments, incorporates their procedures for engaging citizens and industry stakeholders, and encourages continued innovation and experimentation.

The case studies and examples in this commentary describe a national system of partially linked sustainable development laws and an outline of the role each level of government should play in a more cogent strategic approach. The problem with our present national sustainable development legal system is that these linkages are accidental rather than part of a strategy that is integrated as a matter of consistent policy. The vertical and horizontal intersections described above are relatively random within the overall system, not the result of an overt, intentional, and consistent federal policy. It is possible to demonstrate, as we have done, what can happen when federal, state, and local laws are linked and reflexive. Unfortunately, we had to dig deep to find these case studies and to describe their encouraging, if incomplete, results.

The disintegrated, uncoordinated nature of our country's sustainable development legal system-one of our techniques for making choices regarding what happens to our land and resources-is not an incidental matter. Societies that have ignored the warn- 
Socieries that choose to succeed engage effective long-term planning that "characterizes some governments and some political leaders, some of the time."

ings of natural disasters and the degradation of their natural resources in the past have not fared well.

The book Collapse: How Societies Choose to Fail or Succeed reflects on the costs to society of failing to heed the early warnings of long-term problems, such as those caused by climate change. ${ }^{90}$ Societies that choose to succeed engage in effective long-term planning that "characterizes some governments and some political leaders, some of the time." ${ }^{91}$ The integration of sustainable development strategies into an effective legal system will help our country succeed by leveraging all the energies and resources of various levels of government and private stakeholders in a coordinated and competent program aimed at managing climate change.

\section{ENDNOTES:}

1. American Clean Energy and Security Act of 2009, H.R. 2454 , 111 th Cong. (2009) (as passed by the House of Representatives June 26, 2009).

2. Global Warming Solutions ACt of 2006, CAL. HEALTH \& SAFETY $\$ \$ 38500$ et seq. (West 2009).

3. Staff of Senate Commttie an Energr and Commeace, 110 th Cong., Climate Change Legislation Degign White Paper (Comm. Pint 2008)

4. Id.

5. Id. at 6 .

6. Id.

7. See ICLEl-USA Membership List, http://mww. icleiusa.org/ about-iclei/members/member-list; see also |CLEF|-USA Programs, http://www.icleiusa.org/programs/climate/mitigation.

8. The U.S. Conference of Mayors, http://www.usmayors,org/ climateprotection/documents/mcpAgreement.pdf; see also http:// whw. usmayors.org/climateprotection/ist.asp.

9. US. Environmental. Protection Agevcy Pue No. ePA 430-R-09004, InVEnTORY OF U.S. GFEenhOUSE GAS EMISSIONS AND SINKS: $1990-$ 2007, 2-19 (2009) hereinafter EPA Pub. No. EPA 430-R-09-0044 http://uww.epa.gov/climatechange/emissions/dowrloadsog/ InventonUSGhG1990-2007.pdf.

10. Id. at $2-19$.

11. $1 d$.

12. The National Environmental Policy ACt of $1969 ; 42$ U.S.C. $\S \S 4331-4375$ (2008).

13. The Clean Air Act, 42 U.S.C. $\$ \$ 7401-7671$ (2008).

14. Clean Water ACt, 33 U.S.C. $\$ 1251$ et seq. (2008).

15. See John Nolon, Climate Change and Sustainable Development: The Quest for Green Communities, 61 PLANNING \& ENvTL L. 6-7 (Oct. 2009)

16. National Flood Insurance, 42 U.S.C. $\$ \$ 34001$ et seq. (2008). 17. Coastal Zone Management Act of 1972,16 U.S.C. $\$ \$ 1451$ et seq. (2008).

18. VA. CODE ANN. \$15.2-2223 West 2009).

19. VA. Cone ANN. \$15.2-22233.1(A) (West 2009).

20. Minn. Stat. AnN. $\S \S 422.351,473.145$ West 2009).

21. Minnesota Planning Environmental Qualit Board, From Pollgy to Realify: Mogel Ofdinances for Sustanable Development (2000). http://uww.gda.state.mn.us/pdt/2000/eqb/ModelOrdWhole.pdf. 22. CAL. Pub. Res. COBE $\$ \$ 21000$ et seq. West 2009).

23. New York State Depaptiment of Environmental. Congenvation, Office of Air, Engrgiv, and Glimate, Guide for Assessing Energi Use

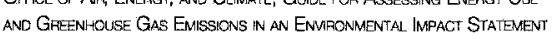

(2009), http://www.dec.ny.gov/docs/administration_pdf/ eisghgpolicy.pdf.

24. ld. at $12-13$.

25. See John R. Noion, The Land Use Stabilization Wedge Strategy: Shifting Ground to Mitigate Climate Change, 34 WM. \& MAFY ENUTL. L. Pa'Y Rev. (torthcoming Dec. 2009).

26. Metropolitan Transportation Planning, 49 U.S.C.A. $\$ 5303($ (h)(1) (E) (Nest 2009).

27. BloOMington, MINN. CCOE CH, 19, 19.29 (2008).

28. See International Code Adoptions, http://uww.iccsafe.org/ government/adoption.html, stating that 42 states plus the District of Columbia have adopted the IECC.

29. See New York ENERGY LAW \& 11-109 (2009). See also New York State Department of State Building Energy Code Page, http:// uww.dos,state.ny.us/code/energycode/nyenergycode.htm

30. See Builders Assistance Project-Code Status, http://www. bcap-energy.org/node/ 5 , providing examples of the models discussed above, with Connecticut as a state that preempts any local action, Massachusetts as an example of a preemptive statewide code with greater \&nergy efficiency standards available for local adoption, and Wyoming as an example of a state with no mandated code.

31. A full text version of the newly adopted Massachusetts Stretch Code is at http://www.mass.gov/Eeops/docs/dps/int/ appendix_120_aa_jul09_09_final.pdf.

32. EPA introduced the Energy Star program in 1992. See EPA, Energy Star: History, http://www.energystar.gov/index $\mathrm{cfm}$ ?c=about.ab_history. See also Residential Energy Services Network Standards, http://www.natresnet.org/standards/ default.htm.

33. CODE OF THE TOWN OF GREENBURGH (N.Y), \$100.15 (2009), hittp:// unw ecode360.com/?custid=GR0237.

34. See Energy Star Qualified Homes 2011 Fact Sheet, May 4. 2009, http://www.energystar.gov/ia/partners/bldrs_lenders raters/downloads/2011_Fact_Sheet.pdf.

35. EPA PUb. No. EPA 430-R-09-0044, supra note 9, at ES-4. 36. U.S. Department of Enetgy, Ofhce of Science, Carbon Sequestration Focus afeas: Enhancing the Natupal Terrestitial Cycie (2004) http://cdiac2.esd. ornlgov/sciencernart.htmiltenchancing. 37. Recent Monthly Mean $\mathrm{CO}_{2}$ at Mauna Loa, http://uwwiestl. noaa.gov/gmd/webdata/ccgg/trends/co2_trend_mlo.pdf. 38. Intergonernimental Pavel on Climate Change, Cumate Change 2007: SMrimesis Rierort, Contpilimons to Wofiking Groups IPCC I, II, \& IIt TO THE 4TH ASSESSMENT 67 (2007), http://mwwipce ch/publications_and_data/publications_ipcc_fourth_assessment report_synthesis_report.htm.

39. Hansen, et al., Target Atmospheric $\mathrm{CO}_{2}$. Where Should Humanity Aim? 2 OPEN ATMOSPHERIC SCI. J., 217-231 (2008) 40. Solomon, et al., Irreversible Climate Change Due to Carbon Dioxide Emissions, 106 Proc. OF THE NAT'L ACAD. Of SCI. 1704-1709 (Feo. 10, 2009).

41. U.S. Climate Change Science. Proggam, Coastal Senstimty to Sea-Leve. Rise: A focus on the Mid-Atlanitic Region 20 (2009), http://www.climatescience.gov/Library/sap/sap4-1/final-report/ default.htm.

42. For more information on the adaptive strategles, See Jessice Bacher, Zoning and Land Use Planning Yielding to the Rising Sea: The Land Use Challenge, 38 REAL EST. L. J. 96, (2009).

43. Miami-Dade County Climate Change Task Force, Science and Technology Committee, Statement on Sea Level in the Com ing Century, in Second Reoort and Initial Recommendations. presented to the Miami-Dade Board of County Commissioners (Apr. 2008), available at $h$ ttp://www miam/dade gov/derm/ library/08-10-04_CCATF_BCC_Package.pdf.

44. Id at 4

45. See The Gity of Bainbridge island Comprehensive Plan, Environmental Element, http://wmw:ci.bainbrldge-isl.wa.us/ comprehensive_plan.aspx.

46. $1 d$.

47. Id. at 8 .

48. The North Carolina Coastal Area Management Act of 1974 , N.C. GEN. STAT. $\$ \$ 1131-100$ to 134.3 (2009), http://dcm2 enr. state.nc.us/rules/cama.htm.
49. 15A N.C. ADMIN. COOE $\$$ O7M.0501 (2008), http://www. nccoastalmanagement.net/Rules/Text/t15a-07m.0500.pdf. 50. North Carolina Design and Construction Guidelines 15 , http://149.168.212.15/mitigation/Library/Full_Tools_and_Tech.pof. 51. Town of Nags Head Hurricane Mitigation and Reconstruction Plan, http://www.csc.noaa.gov/hes/docs/general_info/Location\%20Specific/HURRICANE\%2OAND\%20STORM\%2OMITIGATION\%2OAND\%2ORECONSTRUCTION\%2OPLAN\%2ONAGS\% 2OHEAD\%2ONORTH\%2OCAROLINA.pdf.

52. ld. $\S \S 2-3(\mathrm{~b}), 2-3(\mathrm{c})(1)$.

53. /d. \$2-3(c)(5). Town of Nags Head, N.C., Zoning Code art. XX. §̧ฐ48-741-48-744 (1990), Hurricarie and Storm Reconstruction and Redeveloprnent; General Use Standards for Ocean Hazard Areas, http://www.municode.com/resources/gateway. asp?sid=33\&p/d=13763.

54. See aiso David J. Brower, Anna K. Schwab, \& Bruce M. Bortz, Plan to Make Nags Head, North Carolina, Less Vulnerable to the Impacts of Natural Disasters (Town of Nags Head 1990).

55. The use of the word "resilience" in the context of ecosystems studies has been traced to C.S. Holling, Resilience and Stability of Ecological Systems, 4 AnN. Rev. Ecological Srs. 1 (1973). See Richard J.T. Klein et al. The Resillence of Coastal Megacities to Weather-Related Hazards, in Bullding Safer Cities: The Future of Disaster Risk, World Bank Disaster Risk Management Series No. 3, 101, 111 (Alcira Kriemer et al. eds., 2003), http://www-wds. woridbank.org/servletwDS |Bank_Serviet?pcont=details\&eid= 00001200920031205154931 . See also Dan Henstra et al. Institute for Catastrophic Loss Reduction, Background Paper on Disaster-Resilient Cities $\$ 3.0$ (2004), http://www.infc.go.ca' attormats/pdffrs-rr-2004-03-eng.pdf; Patricia Jones Kershaw. Creating a Disaster-Resilient America: Grand Challenges in Science and Techriology: Summary of a Workshop of the Disasters Roundtable (NAS 2005); Dennis S. MLET, Disasters ay Desion: a Rieassessment of Natupal Hazafos in the United States (Joseph Henry Press, 1999); Cogfeating wTH Nature: Confagenting Natupal Hazaads with Land Use Planning for Sustanabif Communites (Raymond J. Burby ed., 1998), available at http://books. nap.edu/ catalog/5785. html; Ramond J. Burby et al., Creating HazardResilient Communities Through Land Use Planning, 1 Nat. HazaAdes Rev. 99 (2000); David R. Godschalk, Urban Hazard Mitigation: Creating Resilient Cities, 4 NAT. HAZAFDS REV. 136 (2003).

56. Contribution of Working Group II to the Fourth Assessment Report of the Intergovernmental Panel on Climate Change, Climate Change 2007 Impacts, Adaptation and Vutinerability, (2007) (prepared by M.L. Parry et al., eds.), http://www.pec.ch/pdf/assessmentreport/ar4/wg3/ar4-wg3-spm.pdf hereinafter IPCC WG II.

57. U.N. International Strategy for Disaster Reduction, Terminology: Basic Terms of Disaster Risk Reduction, nttp://www.unisdr. org/eng/ibrary/lib-terminology-eng\%20home.htm.

58. Disaster Mitigation Act of 2000, Put. L. No. 106-390 114 Stat. 1552 (codified as amended in scattered sections of 42 U.S.C).

59. Id. at $\$ 322$ (codified as amended at 42 U.S.C. $\$ 5165(a)$ ),

60. $1 d$. at $\$ 203(e)(1)(a) \& \$ 322(c)(1-3)$.

61. N.H. Rev. Stat. Ann. \$\$674:2, 674:16, 674:18 (2009). Chapter 674 of the New Hampshire statutes, http://www.gencourt.state. nh.us/rsa/html/lxiv/674.

62. N.H. Rev. Stat. Ann. \$674:21.

63. Id. at \$483-B:8.

64. City of Dover, N.H., Zoning Code, art. VII, Overriding Districts Ordinance (2005).

65. N.H. Rev. Stat. Ann. $\$ 674.16$.

66. City of Dover, N.H. Zoning Code \$170-27(A).

67. U.N. Convention on the Law of the Sea, arts. $197 \& 207,21$

I.L.M. 1262, Dec. 10, 1982 (entered into force Nov. 16, 1994),

http://www, un.org/Depts/los/index.htm.

68. http://www.ftc.gov/bcp/grnnule/guldes980427.htm

69. City of Boston Zoning Code, § 37-1 (2007), http://umw.bostonredevelopmentauthority.org/pdf/ZoningCode/Article37.pdf.

70. 1d. \$.37-4. See also U.S. Green Building Coucil: About USGBG, http://www.usgbc. org/DisplayPage. asp $\times$ ?CMSPageid $=124$.

71. N.Y. RP Tax $\$ 485-m$. (effective July 21, 2008).

72. 26 U.S.C.A. § 48 (West Supp. 2008). 